\title{
Impact of a health alert and its implementation on flutamide prescriptions for women: an interrupted time series analysis
}

Raquel Vázquez-Mourelle ${ }^{1 *}$, Eduardo Carracedo-Martínez ${ }^{2}$ and Adolfo Figueiras 3,4

\begin{abstract}
Background: Off-label drug use among ambulatory patients is often based on little or no scientific support. This paper reports the impact of a health warning about the risks of off-label flutamide use by women and the actions subsequently implemented by the public health service targeting such use.

Method: The study was undertaken in a region in north-west Spain. We designed a segmented regression model of an interrupted time series, in which the dependent variable was the monthly value of defined daily doses of flutamide per 1000 inhabitants/day (DDD/TID), both total and stratified by sex. The following two data sources were used: flutamide prescriptions billed to the Spanish National Health Service; and flutamide deliveries made by wholesale drug distributors to pharmacies. The intervention assessed consisted of the issue of an official health warning and the actions subsequently taken to implement it.

Results: There was an immediate reduction of $49.33 \%$ in DDD/TID billed to the Spanish National Health Service in respect of women; the mean value of the population percentage of DDD/TID of flutamide billed in respect of women fell from $34.4 \%$ pre-intervention to $23.72 \%$ post-intervention. There was an immediate reduction of $19.92 \%$ (95\%Cl: 6.68-33.15\%) in total DDD/TID invoiced. There were no significant changes in DDD/TID billed in respect of men or in flutamide use in the private medical sector.
\end{abstract}

Conclusions: Off-label drug misuse is a reality among ambulatory patients, even after actions are implemented following a toxicity warning issued by the competent Health Authority.

Keywords: Flutamide, Off-label use, Patient safety, Drug misuse

\footnotetext{
* Correspondence: raquel.vazquez.mourelle@sergas.es

${ }^{1}$ Deputy Directorate-General Galician Health Service (Servicio Gallego de

Salud - SERGAS), Galicia Regional Authority, Edificio Administrativo San

Lázaro s/n, 15703 Santiago de Compostela, Galicia, Spain

Full list of author information is available at the end of the article
}

(c) The Author(s). 2020 Open Access This article is licensed under a Creative Commons Attribution 4.0 International License, which permits use, sharing, adaptation, distribution and reproduction in any medium or format, as long as you give appropriate credit to the original author(s) and the source, provide a link to the Creative Commons licence, and indicate if changes were made. The images or other third party material in this article are included in the article's Creative Commons licence, unless indicated otherwise in a credit line to the material. If material is not included in the article's Creative Commons licence and your intended use is not permitted by statutory regulation or exceeds the permitted use, you will need to obtain permission directly from the copyright holder. To view a copy of this licence, visit http://creativecommons.org/licenses/by/4.0/. The Creative Commons Public Domain Dedication waiver (http://creativecommons.org/publicdomain/zero/1.0/) applies to the data made available in this article, unless otherwise stated in a credit line to the data. 


\section{Introduction}

Flutamide is an oral, nonsteroidal anti-androgen drug, whose only authorised indication is treatment of metastatic carcinoma of the prostate [1]. Aside from a warning about flutamide hepatotoxicity, the Food and Drugs Administration's label (product information sheet) on flutamide also states that "Flutamide is for use only in men. This product has no indication for women, and should not be used in this population, particularly for non serious or nonlife-threatening conditions" [2]. Nevertheless, there have been reports of off-label use of this drug in women to treat polycystic ovary syndrome, androgenetic alopecia, hirsutism, acne and seborrhea [3]. Evidence has been found of a high incidence of the side effects of flutamide, mainly hepatotoxicity, which appears to be especially significant among women [3].

Off-label drug use among ambulatory patients is often based on little or no scientific support [4], something that compromises patient safety and increases healthcare costs [4-7]. Its prevalence in European Union countries ranges from 6 to $72 \%$ [4]. There are studies which conclude that off-label use of a given drug leads to a higher incidence of adverse reactions than does its on-label use [7].

In April 2017, the Spanish Agency of Medicines and Medical Devices (Agencia Española de Medicamentos y Productos Sanitarios/AEMPS) issued an informative health warning, alerting to the problems of flutamide use and advising against its off-label use by women, due to associated risks of hepatotoxicity [8]. The following month the public health service of one Spain's Autonomous Regions sought to implement this warning by suspending all electronic prescriptions of flutamide for women, accompanied by a notice sent to the prescriber. To our knowledge, no other study has analysed the impact of an official health authority warning on the prescription and use of flutamide. Accordingly, the designated aim of this study was to assess the impact of the AEMPS warning on the above Spanish Region and the regional health authority actions implemented in response to this health warning about off-label flutamide use by women.

\section{Materials and methods}

\section{Scope}

The study is the result of an internal control programme developed in 2017 in Galicia, a region in the north-west of Spain with a population of 2.7 million, $98.4 \%$ of which is covered by the Spanish National Health Service (SNHS) under a public health insurance system [9]. Out-of-hospital use of drugs prescribed by SNHS physicians is subject to a financial contribution (co-payment).

In the Galician Autonomous Region there are 23 wholesale drug distributors which supply the area's 1349 retail pharmacy outlets. The SNHS employs 6400 prescribing physicians via the regional public health service [10].

When the AEMPS authorises a drug, it does so accompanied by a legally valid document, setting out the therapeutic indications, dose, contraindications, adverse reactions and/or efficacy. This is known as the "ficha técnica" or "resumen de características del producto"; the European Medicines Agency equivalent is called Summary of product characteristics, and the Food and Drug Administration equivalent is called "Label, product information sheet or Prescription Drug Labeling" [11] .

Prior to 2009, off-label drug use in Spain, as in many other European countries, required prior authorisation by the state drug agency [12, 13]. Currently such use must be of an exceptional nature, be limited to those situations in which no approved therapeutic alternatives exist, be supported by sufficient scientific evidence, and be accompanied by the patient's informed consent and the approval of the committee responsible for treatment protocols in each Autonomous Region [13, 14] .

In 2017, the AEMPS issued a health warning, due to severe cases of hepatotoxicity related to off-label flutamide use among women [8].

\section{Study design and data sources}

We conducted a quasi-experimental ecological timeseries study, using monthly drug usage data from January 2014 to December 2017.

The total information analysed corresponded to:

a) deliveries made by all wholesale drug distributors to retail pharmacy outlets in the region;

b) invoices of officially prescribed prescriptions submitted by retail pharmacy outlets to the SNHS in the region via the official administrative reporting systems; and,

c) use corresponding to the private medical sector, obtained by subtracting retail pharmacy invoicing from total deliveries above, i.e., (b)-(a). Under Spanish Law, retail pharmacies may only sell medicines to individual patients (and not, for instance, to wholesale companies), while individual patients may obtain prescriptions from either the public or the private sector, with flutamide being classed as a drug available exclusively on prescription.

To calculate monthly use, we first calculated the number of Defined Daily Doses (DDD), assuming a DDD of flutamide to be $750 \mathrm{mg}$ [15]. Once transformed into the number of DDD per 1000 inhabitants per day (DDD/ TID) $[16,17]$, these are the basic units that enable time sequences to be examined, adjusting for potential changes in the population, dosage, and/or number of 
pills per prescription or package. The number of DDD/ TID also makes it possible to ascertain the prevalence of utilisation of a given drug. For instance, use of 20 DDD/ TID in a given month can be interpreted to mean that on each day of that month an average of 20 of every 1000 inhabitants had taken one DDD, namely, that about $2 \%$ of the population is taking the medicine in question [18].

\section{Ethical aspects}

This study was conceived as an internal audit, aimed at verifying the result of or compliance with actions implemented by the Public Health Service itself. Official billing data sources are capable of automatically supplying auditors with DDD data stratified by men and women. There was thus no need to set up or directly manage databases in which there might have been identifiable or identified patient data. All this meaning that according to local regulations obtaining an ethics committee approval to carry out this study was not necessary.

\section{Interventions}

The following two consecutive actions were evaluated as a single intervention: (1) the informative health warning issued by the AEMPS in April 2017 [8]; and, (2) its implementation the following month by means of suspending active flutamide prescriptions for women in the SNHS regional service electronic prescription system; this suspension takes the form of a notice about the health warning which is automatically sent to a prescribing physician when a flutamide prescription is generated for a woman patient, with the aim of convincing him/ her to reconsider and cancel it. Even so, the physician may re-activate the prescription, overriding the warning. The notice contains the following message, "Evaluate the continuity of flutamide treatment in accordance with the security warning of the Spanish Agency of Medicines and Medical Devices (https://www.aemps.gob.es/informa/notasInformativas/medicamentosUsoHumano/seguridad/201 7/docs/NIMUH_FV_032017flutamida.pdf)."

\section{Statistical analysis}

For statistical analysis purposes, we constructed a segmented regression model of the interrupted time series for each independent variable analysed [19-22]. In this analysis, the dependent variable was DDD/TID per month, both total and stratified by sex; and the independent variables were:

- time from study onset, which reflects the time trend prior to the study intervention;

- a binary variable which took a value of 0 before and a value of 1 after the intervention, and would thus show the immediate change to each; and,
- a temporal variable which took a value of 0 before and a value of 1,2,3 after the intervention, and would thus show the long-term change in the trend.

To this end, we used the equation described by Linden [19].

In order to reduce any possible autocorrelation, we introduced autoregressive terms into the two models.

Given that the two interventions were consecutive (one in April and the other in May 2017), for statistical calculation purposes April and May 2017 were deemed to be a transition period, with the impact of the two interventions being analysed as one single intervention, by taking the months prior to April 2017 as the preintervention period, and the period subsequent to May 2017 as the post-intervention period.

\section{Results}

Pre-intervention period

The results for the segmented regression show that in the pre-intervention period, the SNHS trend in flutamide prescriptions was downward for both men (annual decrease of $17.46 \%, p<0.05$ ) and women (annual decrease of $16.61 \%, \mathrm{p}<0.05$ ) (see Table 1 and Fig. 1). The slope of this decrease in men was double that of women, which translates as a rise in the percentage of women's prescriptions with respect to the total $(4.93 \% ; p<0.05)$ (Fig. 2). During the pre-intervention stage, no downward trend in prescriptions was observed outside the ambit of the SNHS (see Table 1 and Fig. 3).

\section{Immediate effect}

On evaluating the effect of the interventions on the immediate reduction in flutamide use, SNHS prescriptions among women were observed to decrease by $34.09 \%$ $(p<0.05)$, whilst in men no immediate effect was to be seen (see Table 1 and Fig. 1). The effect on women means that overall prescriptions (sum of men and women) also decreased by $19.92 \%(p<0.05)$. This effect of the intervention on total prescriptions was not in evidence outside the ambit of the SNHS $(p>0.05)$ (see Table 1, and Fig. 3).

From the prevalence of flutamide utilisation by women, it is estimated that prescribers were sent 30 electronic alerts, 13 of which were overridden.

\section{Long-term effect}

Assessment of the mean monthly population value of all SNHS flutamide prescriptions accounted for by women shows that it fell from $34.40 \%$ prior to the intervention to $23.72 \%$ during the post-intervention period. The intervention was not observed to have brought about a change in the long-term slope of any of the study variables (see Table 1). 
Table 1 Segmented regression of time-series data expressed in doses per 1000 inhabitants per day (DDD/TID) of flutamide

\begin{tabular}{|c|c|c|c|c|c|c|}
\hline \multirow[t]{3}{*}{ FLUTAMIDE } & \multirow{2}{*}{\multicolumn{2}{|c|}{ Pre-intervention trend }} & \multicolumn{4}{|c|}{ Post-intervention trend } \\
\hline & & & \multicolumn{2}{|c|}{ Immediate impact } & \multicolumn{2}{|c|}{ Long-term change in trend } \\
\hline & Coefficient $^{a}$ & $95 \% \mathrm{Cl}$ & Coefficient $^{\mathrm{b}}$ & $95 \% \mathrm{Cl}$ & Coefficient $^{c}$ & $95 \% \mathrm{Cl}$ \\
\hline DDD/TID in women billed to SNHS & $-0.00028^{*}$ & -0.00044 to -0.00012 & $-0.00610^{*}$ & -0.00912 to -0.00308 & 0.00004 & -0.00050 to 0.00058 \\
\hline DDD/TID in men billed to SNHS & $-0.00059^{*}$ & -0.00065 to -0.00053 & 0.00283 & -0.00076 to 0.00642 & -0.00058 & -0.00117 to 0.00001 \\
\hline $\begin{array}{l}\text { Sum of DDD/TID for women and } \\
\text { men billed to SNHS }\end{array}$ & $-0.00082^{*}$ & -0.00090 to -0.00074 & $-0.004176^{*}$ & -0.00804 to -0.00031 & 0.00082 & -0.00045 to 0.00101 \\
\hline $\begin{array}{l}\% \text { DDD/TID billed for women with } \\
\text { respect to total DDD/TID billed }\end{array}$ & $0.14262^{*}$ & 0.02488 to 0.25965 & $-13.10626^{*}$ & -18.85022 to -7.36230 & -0.24261 & -1.19333 to 0.70811 \\
\hline $\begin{array}{l}\text { DDD/TID use in healthcare outside } \\
\text { the ambit of the SNHS }\end{array}$ & -0.00003 & -0.00018 to 0.00012 & -0.00269 & -0.01055 to 0.00517 & -0.00114 & -0.00283 to 0.00055 \\
\hline
\end{tabular}

${ }^{*} p<0.05$

SNHS: spanish national health system via the public regional health service

${ }^{a} \beta_{1}$ : slope of the dependent variable until the introduction of the intervention

${ }^{\mathrm{b}} \beta_{2}$ : change in the level of the dependent variable, which occurs in the period immediately after versus the period immediately before the introduction of the intervention

${ }^{c} \beta_{3}$ : difference between the pre- and post-intervention period in the slope of the dependent variable

\section{Discussion}

This study shows that the joint effect of the AEMPS safety warning and the subsequent e-prescription system suspension of active flutamide prescriptions in women was to cut the amount of DDD/TID prescribed in the Galician Health Service by half. This indicates that: (1) there had been prior misuse $[2,3,8]$; and (2) that the Public Health Service actions were effective. Despite the warning issued about the risks of hepatotoxicity, this population group nonetheless maintained a level of flutamide use equivalent to $20 \%$ of the total amount consumed.

Although we were unable to locate any previous study on the impact of a health warning regarding the specific risks of off-label drug use, we did manage to locate studies on the impact of drug health alerts regarding general risks or on-label use, which reported varying results [23-27].

The short space of time which elapsed between the $A E M P S$ warning and the subsequent SNHS regional health service suspension of electronic prescriptions in women meant that the statistical method used could not identify the separate impact of each intervention. However, since the SNHS suspension exclusively affected women in the SNHS, a detailed study by sex made it possible to assess the impact of each of the interventions. Hence, the immediate effect among women was clear, with a reduction to almost half; among men, however, there was no significant change after the health alerts. This could indicate that the impact of the health warning was relatively lower, whereas that of the suspension was relatively higher.

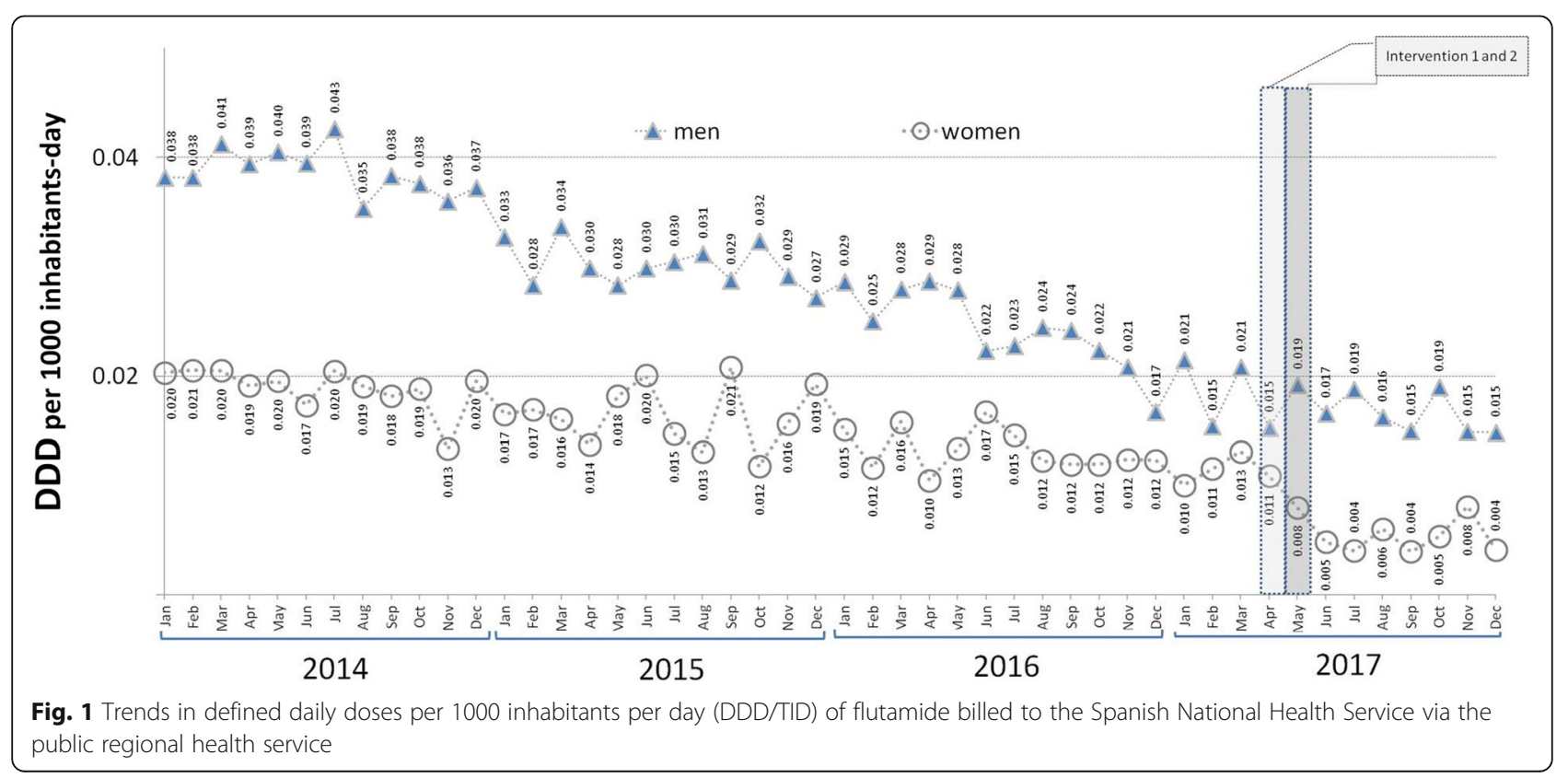




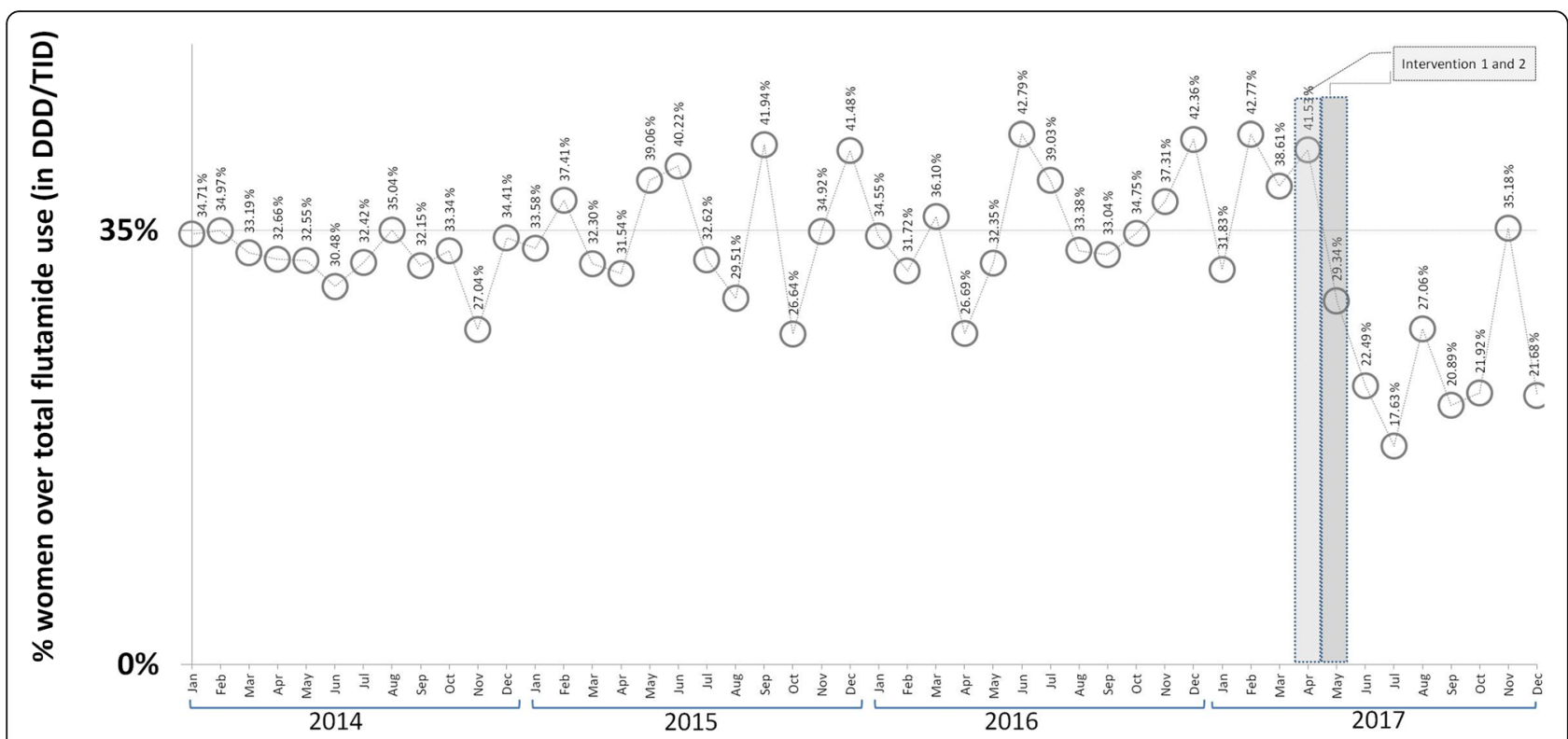

Fig. 2 Trend in the percentage of defined daily doses per 1000 inhabitants per day (DDD/TID) of flutamide in women with respect to total DDD/ TID of flutamide consumed

The finding that the suspension had a greater effect than the alert is further supported by the fact that, following the interventions, total flutamide use underwent an immediate reduction in the SNHS (where a suspension of electronic prescriptions was in place in respect of women), while in healthcare outside the ambit of the SNHS (where no such suspension took place) this did not occur.

The results also indicate that, during the pre-intervention period, there was a rise in the percentage of women who engaged in off-label flutamide use. This fact alone justifies the need for a specific safety warning for this group.

Our study observed that, despite the health warning and suspension of active electronic prescriptions, offlabel flutamide use continued. This may be due to:

(i). off-label pharmaceutical marketing [28], though illegal and potentially subject to sizeable penalties [29];

(ii). prescribers' ignorance of prescribing obligations. Off-label drug use is only legal, if each and every

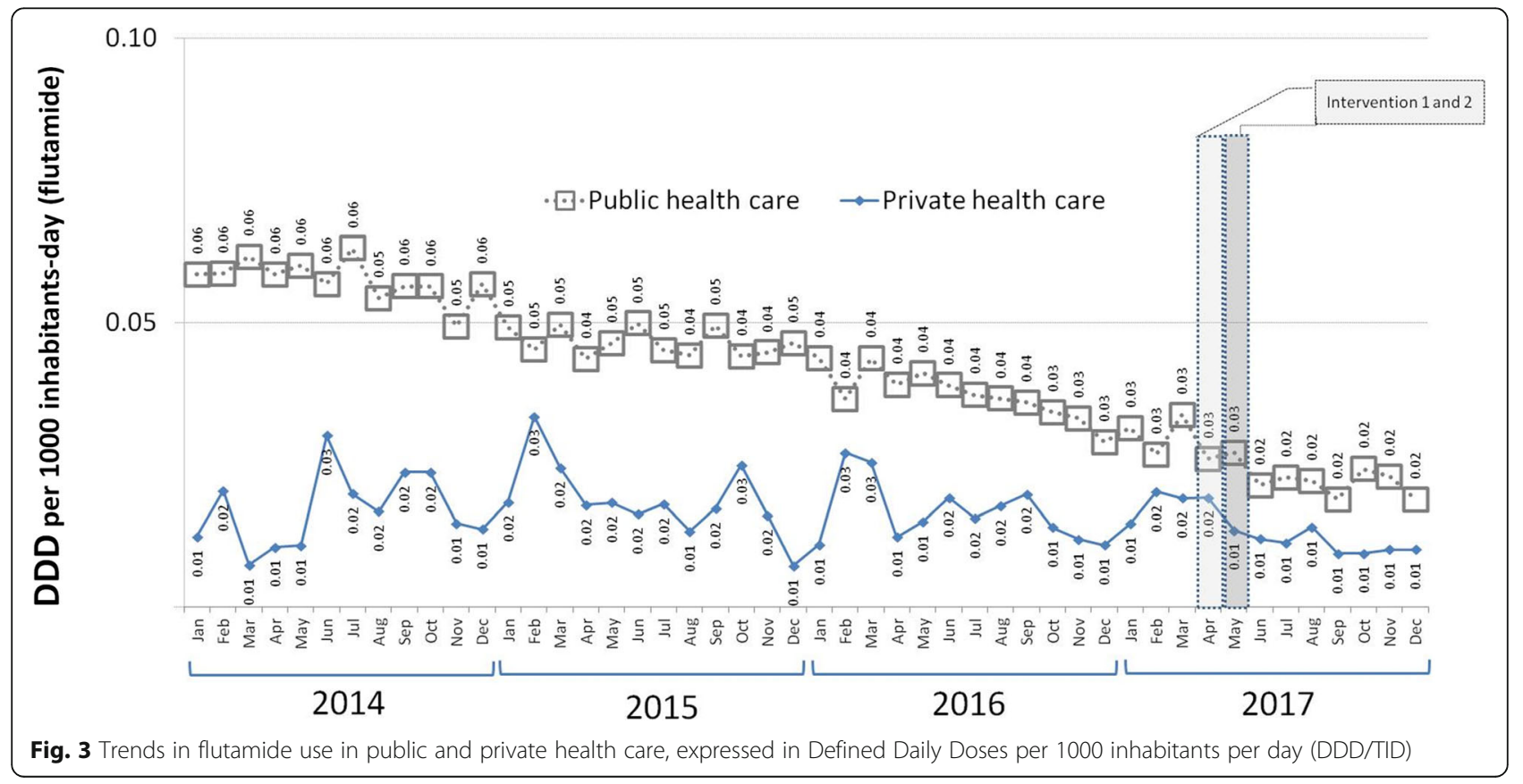


one of a series of requirements is met, i.e., existence of sufficient scientific evidence, lack of other approved therapeutic alternatives, approval by a regional committee $[13,14]$, and the patient's informed consent [30]. Failure to comply with these requirements amounts to an unlawful act, which gives rise to disciplinary repercussions as well as the related healthcare and economic harm [5];

(iii).pressure resulting from complacency towards the patient, with patient pressure having been seen to induce drug prescribing [31]; and/or,

(iv).maintenance of state funding in the absence of clear explicit statutory provisions which would expressly exclude off-label use from public funding in Spain, despite the fact that theoretically, off-label use is not reimbursed [4-6].

To decrease the use of this drug, measures with proven effectiveness could be implemented, such as: (a) submitting the dispensing of flutamide to a prior authorisation requirement [31-36]; (b) introducing druginspection programmes [37, 38]; or, (c) returning Spain to the system that is still in place in other European countries, whereby off-label use must be previously authorised by the state drug agency [4].

This study's limitations would arguably include its ecological design or the lack of a control group, though, as other potentially related external factors should have affected both sexes equally, the men's group could be regarded as a control group for the women. A further limitation might lie in our not having information about possible deliveries made directly by pharmaceutical companies or authorised wholesale drug distributors outside the study region, though use of this circuit is not standard practice. Lastly, the two actions (the issue of the health warning and its subsequent implementation) were very close in time, thereby rendering it impossible to assess their respective effects separately.

\section{Conclusion and implications}

Off-label misuse of drugs is a reality among ambulatory patients, even after the issue of a toxicity warning by the state regulatory agency. Accordingly, the implementation of strict control programmes in health services is called for, as well as a specific, clear regulation in line with the necessary degree of healthcare safety required by offlabel use.

\section{Abbreviations}

AEMPS: Spanish Agency of Medicines and Medical Devices; SNHS: Spanish National Health Service; DDD: Defined daily doses; DDD/TID: Defined daily doses per 1000 inhabitants per day; DDD/100 s-d: Defined daily doses per 100 stays and a day

\section{Authors' contributions}

Vázquez-Mourelle conceived the study and collected, validated and standardised the data; Figueiras and Carracedo-Martínez developed the methodological design of the study; and all three authors jointly interpreted the data and results. Vázquez-Mourelle wrote the paper, and Figueiras and Carracedo-Martínez were responsible for the critical review of the different versions, making major contributions. All authors approved the final version of the manuscript.

\section{Funding}

No funding.

\section{Availability of data and materials}

The datasets used and/or analysed during the current study are available from the corresponding author on reasonable request.

Ethics approval and consent to participate

Not applicable.

Consent for publication

Not applicable.

\section{Competing interests}

The authors declare that they have no competing interests.

\section{Author details}

${ }^{1}$ Deputy Directorate-General Galician Health Service (Servicio Gallego de Salud - SERGAS), Galicia Regional Authority, Edificio Administrativo San Lázaro s/n, 15703 Santiago de Compostela, Galicia, Spain. ²Santiago de Compostela Health Area Authority, Galician Health Service, Santiago de Compostela, Galicia, Spain. ${ }^{3}$ Department of Preventive Medicine and Public Health, Faculty of Medicine, University of Santiago de Compostela,

Consortium for Biomedical Research in Epidemiology \& Public Health (CIBER en Epidemiología y Salud Pública - CIBERESP), Santiago de Compostela, Galicia, Spain. ${ }^{4}$ Health Research Institute of Santiago de Compostela (IDIS), Santiago de Compostela, Galicia, Spain.

Received: 20 October 2019 Accepted: 19 June 2020

Published online: 29 June 2020

\section{References}

1. Spanish Medicines Agency. Summary of product characteristics: Flutamide 250 mg. 2018. https:/cima.aemps.es/cima/dochtml/ft/62912/FT_62912.html. Accessed 15 July 2018.

2. Food and Drugs Administration. Flutamide label. https://www.accessdata. fda.gov/drugsatfda_docs/label/2001/18554s23lbl.pdf. Accessed 17 Apr 2020.

3. Giorgetti R, di Muzio M, Giorgetti A, Girolami D, Borgia L, Tagliabracci A. Flutamide-induced hepatotoxicity: ethical and scientific issues. Eur Rev Med Pharmacol Sci. 2017;21(1 Suppl):69-77.

4. European Commission. Study on off-label use of medicinal products in the European Union. 2017.https://ec.europa.eu/health/sites/health/files/files/ documents/2017_02_28_final_study_report_on_off-label_use_.pdf. Accessed 18 June 2018.

5. Radley DC, Finkelstein SN, Stafford RS. Off-label prescribing among officebased physicians. Arch Intern Med. 2006;166(9):1021-6.

6. Gupta SK, Nayak RP. Off-label use of medicine: perspective of physicians, patients, pharmaceutical companies and regulatory authorities. J Pharmacol Pharmacother. 2014:5(2):88-92.

7. Eguale T, Buckeridge DL, Verma A, Winslade NE, Benedetti S, Hanley JA, et al. Association of off-label Drug use and Adverse Drug Events in an adult population. JAMA Intern Med. 2016;176(1):55-63.

8. Spanish Medicines Agency. Safety information note: Flutamida. 2017. https://www.aemps.gob.es/informa/notasInformativas/ medicamentosUsoHumano/seguridad/2017/NI-MUH_FV_03-2017-flutamida. htm. Accessed 18 Feb 2018.

9. Vázquez-Mourelle R, Carracedo-Martínez E, Figueiras A. Impact of removal and restriction of me-too medicines in a hospital drug formulary on in- and outpatient drug prescriptions: interrupted time series design with comparison group. Implementation Sci. 2019;14:75. https://doi.org/10.1186/ s13012-019-0924-0. 
10. Ministerio de Sanidad, Consumo y Bienestar. Informe Anual del Sistema Nacional de Salud 2016. https://www.mscbs.gob.es/estadEstudios/ estadisticas/sisInfSanSNS/tablasEstadisticas/InfAnualSNS2016/Informe_Anual_ SNS_2016_completo.pdf. Accessed 18 Apr 2018.

11. Lal $R$, Kremzner M. Introduction to the new prescription drug labeling by the Food and Drug Administration. Am J Health Syst Pharm. 2007;64(23): 2488-94.

12. European Union. Study on off-label use of medicinal products in the European Union. 2017. https://ec.europa.eu/health/sites/health/files/files/ documents/2017_02_28_final_study_report_on_off-label_use_.pdf. Accessed 18 June 2018.

13. Real Decreto por el que se regula la disponibilidad de medicamentos en situaciones especiales. R.D. N. 1015/2009 (19 June 2009).

14. Real Decreto Ley por el que se aprueba el texto refundido de la Ley de garantías y uso racional de los medicamentos y productos sanitarios. RDL No 1/2015 (24 July 2015)

15. World Health Organization. WHO Collaborating Centre for Drug Statistics and Methology Definition and general considerations. 2017. https://www. whocc.no/ddd/definition_and_general_considera/. Accessed 15 Apr 2017.

16. World Health Organization. ATC/DDD Index. 2017. https://www.whocc.no/ atc_ddd_index/. Accessed 12 Dec 2017.

17. Capellá D, Laporte JR. Métodos aplicados en estudios descriptivos de utilización de los medicamentos. In: Laporte JR, Tognoni G, editors. Principios de epidemiología del medicamento. 2nd ed. Barcelona: Ediciones Científicas y Técnicas; 1993. p. 67-93.

18. Spanish Medicines Agency. Observatorio de uso de medicamentos. Metodología utilizada. https://www.aemps.gob.es/medicamentos-de-usohumano/observatorio-de-uso-de-medicamentos/metodologia/?lang=en. Accessed 17 Apr 2020.

19. Linden A. Conducting interrupted time series analysis for single and multiple group comparisons. Stata J. 2015;15(2):480-500.

20. Sruamsiri R, Wagner AK, Ross-Degnan D, Lu CY, Dhippayom T, Ngorsuraches $\mathrm{S}$, et al. Expanding access to high-cost medicines through the E2 access program in Thailand: effects on utilisation, health outcomes and cost using an interrupted time-series analysis. BMJ Open. 2016;17:e008671. https://doi. org/10.1136/bmjopen-2015-008671.

21. Kontopantelis E, Doran T, Springate DA, Buchan I, Reeves D. Regression based quasi-experimental approach when randomisation is not an option: interrupted time series analysis. BMJ. 2015;9:350-h2750.

22. Wagner AK, Soumerai SB, Zhang F, Ross-Degnan D. Segmented regression analysis of interrupted time series studies in medication use research. J Clin Pharm Ther. 2002;27(4):299-309.

23. Carracedo-Martínez E, Pia-Morandeira A. Influence of health warnings on the use of rosiglitazone and pioglitazone in an area of Spain: a time-series study. SAGE Open Med. 2016;4:1-5. https://doi.org/10.1177/ 2050312116653054.

24. Peiro S, Cervera P, Bernal-Delgado E. Selective serotonin reuptake inhibitors in childhood depression: a soap opera that reflects serious problems of drug safety. Gac Sanit. 2005;19(5):401-6.

25. Carracedo-Martínez E, Pia-Morandeira A, Figueiras A. Impact of a health safety warning and prior authorisation on the use of piroxicam: a timeseries study. Pharmacoepidemiol Drug Saf. 2012;21(3):281-4. https://doi.org/ 10.1002/pds.2275

26. Carracedo-Martínez E, Pía-Morandeira A. Impact of a health safety warning on strontium ranelate utilization. Gac Sanit. 2010;24(2):151-3.

27. Carracedo Martínez E, Pía-Morandeira A. Influence of a regulatory safety warning on the use of telithromycin. Med Clin (Barc). 2011;136(10):456-7.

28. Fundación Instituto Catalán de Farmacología. Procure evitar los neurolépticos fuera de la psiquiatría. Sobre todo los más nuevos. Butlletí Groc 2017;30:1-7. https://www.icf.uab.cat/assets/pdf/productes/bg/es/bg3 01.17e.pdf. Accessed 12 Dec 2017.

29. Department of Justice. Warner-Lambert to Pay $\$ 430$ Million to Resolve Criminal \& Civil Health Care Liability Relating to Off-Label Promotion. 2004. https://www.justice.gov/archive/opa/pr/2004/May/04_civ_322.htm. Accessed 12 Aug 2018.

30. Aagaard L, Kristensen K. Off-label and unlicensed prescribing in Europe: implications for patients' informed consent and liability. Int J Clin Pharm. 2018;40(3):509-12.

31. Gonzalez-Gonzalez C, López-Vázquez P, Vázquez-Lago JM, Piñeiro-Lamas M, Herdeiro MT, Arzamendi PC, et al. Effect of Physicians' Attitudes and
Knowledge on the Quality of Antibiotic Prescription: A Cohort Study. PLoS One. 2015;10(10):e0141820. https://doi.org/10.1371/journal.pone.0141820.

32. Kahan NR, Chinitz DP, Waitman D, Kahan E. When gatekeepers meet the sentinel: the impact of a prior authorization requirement for cefuroxime on the prescribing behaviour of community-based physicians. Br J Clin Pharmacol. 2006;61(3):341-4.

33. Fischer MA, Schneeweiss S, Avorn J, Solomon DH. Medicaid priorauthorization programs and the use of cyclooxygenase-2 inhibitors. N Engl J Med. 2004:351(21):2187-94.

34. Carracedo-Martínez E, Pia-Morandeira A, Figueiras A. Trends in celecoxib and etoricoxib prescribing following removal of prior authorization requirement in Spain. J Clin Pharm Ther. 2017;42(2):185-8.

35. Gamble JM, Majumdar SR, Johnson JA, McAlister FA, Simpson SH, Eurich DT. Changes in thiazolidinedione use and outcomes following removal of a prior-authorization policy controlled time-series analysis. Med Care. 2014;52: 47-55.

36. Gao L, Tadrous M, Knowles S, Mamdani M, Paterson JM, Juurlink D, et al. Prior authorization and Canadian public utilization of direct-acting Oral anticoagulants. Health Policy. 2017;13(2):68-78.

37. Vázquez-Mourelle R, Carracedo-Martínez E, Ces Gens E, Cadórniga Valiño L, Álvaro Esteban P, Pose Reino JM. Control measures for anabolic androgenic steroid medicines. Gac Sanit. 2015;29(4):304-7.

38. Vázquez-Mourelle R, Carracedo-Martínez E, Figueiras A. Impact of health authority control measures aimed at reducing the illicit use of anabolicandrogenic steroids. Eur Addict Res. 2018;24(1):28-36.

\section{Publisher's Note}

Springer Nature remains neutral with regard to jurisdictional claims in published maps and institutional affiliations.

\section{Ready to submit your research? Choose BMC and benefit from:}

- fast, convenient online submission

- thorough peer review by experienced researchers in your field

- rapid publication on acceptance

- support for research data, including large and complex data types

- gold Open Access which fosters wider collaboration and increased citations

- maximum visibility for your research: over $100 \mathrm{M}$ website views per year

At BMC, research is always in progress.

Learn more biomedcentral.com/submissions 